\title{
Effect of Compositing Precooked Cowpea with Improved Malted Finger Millet on Anti-Nutrients Content and Sensory Attributes of Complementary Porridge
}

\author{
Cyprian 0. Syeunda, Joseph 0. Anyango*, Abdul K. Faraj \\ Department of Dairy and Food Science and Technology, Egerton University, Njoro, Kenya \\ Email: *ajochieng@egerton.ac.ke
}

How to cite this paper: Syeunda, C.O., Anyango, J.O. and Faraj, A.K. (2019) Effect of Compositing Precooked Cowpea with Improved Malted Finger Millet on AntiNutrients Content and Sensory Attributes of Complementary Porridge. Food and $\mathrm{Nu}$ trition Sciences, 10, 1157-1178. https://doi.org/10.4236/fns.2019.109084

Received: August 30, 2019

Accepted: September 26, 2019

Published: September 29, 2019

Copyright ( 2019 by author(s) and Scientific Research Publishing Inc. This work is licensed under the Creative Commons Attribution International License (CC BY 4.0).

http://creativecommons.org/licenses/by/4.0/

\begin{abstract}
Protein energy malnutrition remains a huge burden in Sub-Saharan Africa. Principally, it is due to children being fed on millet gruels which are high in carbohydrates, and low protein. Moreover, they contain significant amounts of anti-nutrients such as phytates, phenols and tannins. Compositing of malted finger millet flour with other flours has potential for improving the nutritional quality and sensory attributes of these foods. The objective of this study was to determine the effect of compositing malted finger millet flour with cowpea on the anti-nutritional contents and sensory properties of formulated baby weaning food. Mixing selected improved finger millet varieties with precooked cowpea flour was based on WHO recommended levels. There was a significant $(\mathrm{p}<0.05)$ reduction in total phenolic content, tannin content and phytic acid by $41 \%, 50 \%$, and $44 \%$, after compositing with malted finger millet and precooked cowpea at $10.32 \%, 21.26 \%$ and $32.75 \%$, respectively. Cooking process significantly reduced amount of trypsin inhibitors, and other anti-nutrients both in cowpea and complementary porridge. Loadings from principal component analysis (PCA) of 17 sensory attributes of porridge showed that approximately over $80 \%$ of the variations in sensory attributes were explained by the first four principal components. Reductions in texture attributes (stickiness and viscosity) and astringency aftertaste corresponded to increase in overall aroma and flavour of the porridge in terms of malty flavour and aroma. Although inclusion of $32.75 \%$ precooked cowpea gave the highest reduction in anti-nutrients, it resulted in cooked cowpea flavour. For consumer acceptability, it may require masking by use of commercial flavours. Therefore this work shows that malted finger millet-precooked cowpea have potential to be used in formulating cultural acceptable complementary food.
\end{abstract}




\section{Keywords}

Finger Millet, Cowpea, Malting, Anti-Nutrients, Weaning Food

\section{Introduction}

Weaning is the art of introducing semi-solid or solid food to infant life or complete discontinuation of breast milk by the introduction of semi-solid or solid food to the diet. Hence it involves expanding the infant's diet to include other drinks and food rather than infant formula or breast milk [1]. During this dietary transition, the nutritional requirements for the brain and growth of the infant are high. Some researchers [2] have observed that, among developing countries, during child feeding practices, weaning period usually starts at the age of 4 - 6 months, and continues up to 2 - 3 years. During weaning, the transitional phase from liquid to solid or semi-solid food is critical to an infant's life, since nutritional deficiency in the form of protein-energy-malnutrition may likely to occur.

Appropriate nutritional intake is important especially for infants, because it is the most critical stage of human development [3]. During the first six months of life, infants obtain all the energy and nutrient requirements from breast milk. By the age of six months, they need complementary or additional foods to meet their needs for proper growth and development [4]. The principal food given to children at 6 to 36 months of age in many parts of Kenya is a cereal-based thin porridge (uji). Mainly, it is made from maize (Zea mays), sorghum (Sorghum bicolour L. Moench), finger millet (Eleusine coracana), which are sometimes supplemented where possible, with banana (Musa acuminata) fruit, non-cereals such as pumpkin (Cucurbita maxima), cassava (Manihot esculenta) sweet potatoes (Ipomea batatas), dagaa (Rastrineobola argentea) or milk [5]. However, these weaning foods are typically gruels of high bulk, low protein content and quality [6]. High dietary bulk in these gruels makes it hard for children fed on them to adequately meet their nutritional requirement, partly because a young child has a less mature gastrointestinal tract which results in digestion difficulty [7]. This causes a huge malnutrition implication, as is it difficult to meet a child's nutritional needs. Therefore utilization of traditional processing techniques such as malting seems crucial in developing a nutrient dense and acceptable complementary food that can be used to improve food security among the most impoverished communities.

Finger millet (Eleusine coracana) stands as the sixth most important cereal grain in the world in terms of production. It sustains one-third of the world's population. It is able to grow to a height of $0.4-1.0 \mathrm{~m}$ while the length of its panicles varies between 3 and $13 \mathrm{~cm}$ [8]. The crop is well adapted to arid, marginal land probably due to its $\mathrm{C} 4$ photosynthetic nature since it is able to use water efficiently, hence making it suitable for poor farmers who inhabit these 
areas [8]. It is an important crop because of its capability to be stored for long. Morphologically, the seeds roughly vary from spherical to oval and dimension range between 1 to $2 \mathrm{~mm}$, with a 1000 kernel weight approximately $2.5 \mathrm{~g}$ [9]. Nutrient profile of finger compares favourably with other cereals, especially rice and sorghum. It is rich in hydrophobic amino acids, carbohydrates and minerals, especially calcium. However, different reviews have shown that the presence of anti-nutritional factors such as condensed tannins and phytate in finger millet adversely affects the bioavailability of proteins, carbohydrates, and minerals [8] [9].

Cowpea is a drought and heat tolerant crop that is able to survive arid or semi-arid soil conditions experienced in sub-Saharan-Africa. In Kenya, where there are many poor subsistence farmers, cowpea could be a suitable alternative to expensive sources of protein such as meat and fish, because of its unique attributes and low agronomical requirement in terms of [10]. It is rich in protein when compared to cereals such as rice, sorghum and finger millet. Therefore, to improve nutritional status of poor farmers, less costly, nutritious plant sources such as pulses can be a source of cheap protein. Cowpea is a strong candidate for fortification of cereal-based weaning foods in Africa to reduce PEM, because of it contains good quality protein. However, it also contains oligosaccharides; verbscose and stachyscose, associated with flatulence, and trypsin inhibitors, but these can be reduced significantly through cooking [11].

Various researchers have studied the nutritional and sensory quality of different food products with varying levels of cowpea. Examples include, porridge made from sorghum-cowpea [12], injera (fermented flatbread), ugali (unfermented thick porridge) and uji (unfermented thin porridge) made from composites of African sorghum and cowpea [13]. The results have been promising. However, compositing with cowpea has also been shown to affect sensory attributes of formulated foods negatively. For instance, [14] working on sorghum-cowpea thick porridge, found that high proportions of cowpea beyond $30 \%$ introduced a noticeable be any flavour. This negatively influenced sensory attributes of the product. Furthermore, there is little information on the effect of malting and addition of precooked cowpea on complementary porridge. Therefore it is necessary to find out how addition of precooked cowpea to malted finger millet would affect anti-nutrient and sensory attributes of the complementary food. Hence, the objective of this study was to determine the effect of compositing agronomically improved malted finger millet flour with cowpea on antinutrient content and sensory properties of formulated baby weaning food.

\section{Materials and Methods}

The study was conducted at Guildford Dairy Institute, Department of Dairy and Food Science and Technology, Egerton University. Anti-nutrients determination was carried out at Kenya Agricultural and Livestock Research Organisation (KALRO) food laboratory in Njoro, Kenya and Biotechnology Laboratory at 
Egerton University, Kenya. Two, improved finger millet varieties were sourced from Egerton University Agro-Science Park, and were previously grown in a low altitude environment (Bomet County, Kenya). Improved cowpea varieties were Kundesoko and Kundefaulu sourced from KALRO Katumani Research Centre in Machakos County. The finger millets used had the following attributes: Snapping Green Early is easy to harvest and thresh and KNE 741 variety used is super early in maturity and suitable to low altitude. Kundesoko is a dual variety, high yielding, with long pods that are mostly above canopy for easy harvesting, while, Kundefaulu brown coloured, with grain that are large and with long pods loosely attached to pedicel, hence preferred by farmers as it fetches better price in the market.

\subsection{Food Preparation Procedures}

\section{Preparation of malted finger millet flour}

Malting of the finger millet was carried out with modification as described by [15] Finger millet grains ( $1 \mathrm{~kg}$ ) were cleaned three times using tap water and steeped in 2-L of water for $24 \mathrm{~h}$. Water was changed after every $6 \mathrm{~h}$ during steeping (maintain good air circulation). After steeping, the grains were then germinated in forced draft oven at ambient temperature of $\approx 25^{\circ} \mathrm{C}$. Tap water was sprinkled regularly onto the grains and mixed to ensure uniform malting. After $48 \mathrm{~h}$, the grains were dried in an oven at $48^{\circ} \mathrm{C} \pm 2{ }^{\circ} \mathrm{C}$ for $24 \mathrm{~h}$, to a moisture content of $10 \%$, and then milled using a Microphyte lab disintegrator model Fz102 (Tianjin, China), fitted with $500-\mu \mathrm{m}$ sieve to give whole grain flour, and then stored at $9^{\circ} \mathrm{C}-10^{\circ} \mathrm{C}$ until further analyses.

\section{Preparation of precooked cowpea flour}

Mature and dry grains (1 kg) were cleaned, which involved removing of foreign matter, broken seeds and immature seeds. The grains were then washed using tap water, and placed in metallic pot; tap water was then added until the grains were all submerged. They were cooked in boiling water $\left(93^{\circ} \mathrm{C}\right)$ for approximately $1 \mathrm{~h}$, and then dried in an oven set at $50^{\circ} \mathrm{C}$ to a moisture content of $10 \%$. Dried grains were then milled using a Microphyte lab disintegrator model Fz102 (Tianjin, China), fitted with $500-\mu \mathrm{m}$ sieve to give whole grain flour, and then stored at $9-10^{\circ} \mathrm{C}$ until further analyses.

\section{Preparation of composite flours}

Malted finger millet and precooked cowpea flours were composited at $10.34 \%$, $21.26 \%$ and $32.75 \%$ to reflect 9 - $13 \mathrm{~g}$ per day, protein requirements of the infants 1 to 3 years old as outlined by [16] with $0 \%$ cowpea (100\% unmalted finger millet as negative control /malted finger millet as positive control)

Preparation of porridge flours

Composite flour $(30 \mathrm{~g}$ ) was mixed with 50 - $\mathrm{mL}$ cold water to form a thick batter. Water $(100 \mathrm{~mL})$, in a metallic pot, was brought to boil and then the batter added with continuous stirring using a cooking stick until the mixture formed a viscous gruel. The porridge was steamed on low heat for $10 \mathrm{~min}$ and then cooled on plates, later dried in forced draft oven at $60^{\circ} \mathrm{C}$ to a moisture content of $10 \%$. 
Dried porridge was milled using a Microphyte lab disintegrator model Fz102 (Tianjin, China), fitted with $500-\mu \mathrm{m}$ sieve to give flour, and then stored at $9^{\circ} \mathrm{C}$ $10^{\circ} \mathrm{C}$ for further analyses.

\subsection{Analyses}

\section{Determination of moisture content}

Moisture content of the samples was determined using oven-drying method according to AACC International [17] Method 44 - 15 A. It involved exposing samples to a single stage air oven drying at $103^{\circ} \mathrm{C}$ for $3 \mathrm{~h}$. Moisture content was then calculated as the loss in weight expressed as a percentage of the original weight of a sample.

Determination of total phenols content

Total phenolics of the samples were analysed using the Folin-Ciocalteu method [9] [18]. Flour (300 mg), was extracted with 30-mL of acidified methanol for $1 \mathrm{~h}$ at room temperature and then centrifuged at 2060-xg for 20 min using Eppendorf centrifuge (Model 5804, Eppendorf, Hamburg, Germany), decanted and three replicate supernatants obtained. Sample extracts $(0.5-\mathrm{mL})$ were mixed with 2.5-mL of Folin-Ciocalteu phenol reagent in a $50-\mathrm{mL}$ centrifuge tubes containing $10-\mathrm{mL}$ distilled water, $7.5-\mathrm{mL}$ of $20 \%(\mathrm{w} / \mathrm{v})$. Sodium carbonate was then added within 8 min after addition of the Folin-Ciocalteu reagent. The contents were then made up to volume with distilled water, stoppered and thoroughly mixed. Tubes were left to stand at room temperature for $2 \mathrm{~h}$ and absorbance read at $760 \mathrm{~nm}$ using a UV/VIS Spectrophotometer (model Pharmaspec UV1700, Shimadzu, Japan). Sample blank were included in which distilled water replaced the sample. Catechin was used as standard. Total phenol was expressed as mg catechin equivalent per 100mg sample.

\section{Determination of condensed tannin content}

Modified Vanillin- $\mathrm{HCl}$ in methanol method [19] was used in determining condensed tannins Ground samples $(0.25 \mathrm{~g})$ were weighed into a $50 \mathrm{ml}$ Erlenmeyer flask, and then $10-\mathrm{mL}$ of $4 \% \mathrm{HCI}$ in methanol $(\mathrm{v} / \mathrm{v})$ was added and the content shaken for 20 min using Ratek Orbital Incubator (Boronia, Victoria, Australia). Samples were centrifuged at $2060 \times \mathrm{g}$ for $20 \mathrm{~min}$ at room temperature using Eppendorf centrifuge. Sample extracts $(1-\mathrm{mL})$, were then mixed with $5-\mathrm{mL}$ of Vanillin-HCI reagent. The specific reagent (Vanillin-HCI) for the determination was prepared just before use by mixing equal volumes of $1 \%$ Vanillin in methanol (w/v) and $8 \%$ conc. HCI in methanol (v/v). Absorbance was read at $500 \mathrm{~nm}$ using UV/VIS Spectrophotometer exactly after $20 \mathrm{~min}$. Sample blanks in which $4 \% \mathrm{HCI}$ in methanol replaced vanillin reagent were included. For zero setting of the colorimeter, $1-\mathrm{mL}$ of a blank $(1 \% \mathrm{HCl}$ in methanol) was used. Catechin was used as standard. Condensed tannin was expressed as mg catechin equivalent per $100 \mathrm{mg}$ sample.

\section{Determination of phytic acid content}

Phytic acid analysis was based on precipitation of phytate [20], with some modifications. Sample (500 mg) was accurately weighed and phytate extracted 
using $50 \mathrm{~mL}$ of $3 \%$ Trichloroacetic acid by shaking on Ratek Orbital Incubator for $40 \mathrm{~min}$. The suspension was then centrifuged at ( $3000 \times \mathrm{g}, 10 \mathrm{~min})$ using Eppendorf centrifuge, $10-\mathrm{mL}$ aliquot of the supernatant was transferred to $50-\mathrm{mL}$ centrifuge tube and $4 \mathrm{~mL}$ of $\mathrm{FeCl}_{3}$ solution added rapidly. The contents in the tubes were then heated in boiling water for $45 \mathrm{~min}$, then centrifuged at $(3000 \times \mathrm{g}$, $10 \mathrm{~min}$ ) using Eppendorf centrifuge and the clear supernatant decanted. The precipitate was then washed twice by dispersing in $25-\mathrm{mL} 3 \% \mathrm{TCA}$, and then heated in boiling water for $10 \mathrm{~min}$, then centrifuged at $(3000 \times \mathrm{g}, 10 \mathrm{~min})$ using Eppendorf centrifuge, and washed again with $20-\mathrm{mL}$ distilled water. The precipitate was then dispersed in $5-\mathrm{mL}$ of distilled water and $3-\mathrm{mL}$ of $1.5 \mathrm{~N} \mathrm{NaOH}$ added, then topped up to $30-\mathrm{mL}$ with distilled water and heated for $30 \mathrm{~min}$ in boiling water. The contents were then filtered using Whatman No. 2 filter paper with pore size of $8 \mu \mathrm{m}$, and then washed with $70-\mathrm{mL}$ hot distilled water. The precipitate was transferred and dissolved into the $100-\mathrm{mL}$ volumetric flask con-

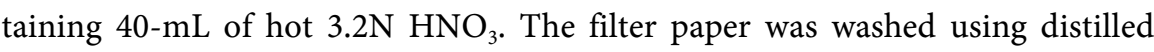
water, and the washings collected in the same flask. The flask was cooled to room temperature and the volume made to $100-\mathrm{mL}$ with distilled water. An aliquot $(5-\mathrm{mL})$ was transferred to another $100-\mathrm{mL}$ volumetric flask, and mixed with $65-\mathrm{mL}$ distilled water, $20-\mathrm{mL}$ of $1.5 \mathrm{M}$ Potassium thiocyanate (KSCN) then added. The volume was made to $100-\mathrm{mL}$ with distilled water, and colour read at $480 \mathrm{~nm}$ using a UV/VIS spectrophotometer within one min. Reagent blank in which distilled water replaced the sample was included. Calibration curve was made from Iron (III) nitrate solution stock solution. Iron (In micrograms), present in test solution was determined from the calibration curve and phytate $\mathrm{P}$ calculated as follows,

Phytate P mg/100g sample $=[\mathrm{Fe}(\mu \mathrm{g}) \times 15] /$ Weight of sample $(\mathrm{g})$.

Recruitment and screening of the panel

Egerton university Department of Dairy and Food Science and Technology students, and academic staff who were willing to consume finger millet porridge, and had some experience of descriptive sensory evaluation and did not suffer from any food allergies, were invited through telephone, emails, and notices to participate in sensory evaluation. Twenty individuals responded, and attended an introduction session. Ten persons were already trained panellists: of these, nine confirmed their availability. They were screened for sensory acuity, using screening methods; identification tastes (sweet, salty and sour) and identification of sensory attributes that describe taste, flavour and appearance of different complementary porridge. A final panel of ten judges: nine previously trained and one recruit were selected and used.

Training of the panel

The panel was trained for 4 days in $2 \mathrm{hr}$ sessions per day, according to generic descriptive method described by [21]. During the training, each panellist described the differences between the porridge twice. For purposes of evaluation, descriptive terms and scale anchors were developed, defined and agreed (Table $1)$. 
Table 1 . Terms used by descriptive sensory panel to describe the sensory attributes of the porridge.

\begin{tabular}{|c|c|c|c|}
\hline Descriptor' & Definition & Reference & Rating scale \\
\hline \multicolumn{4}{|l|}{ Aroma } \\
\hline Overall aroma intensity & Intensity of the aroma of porridge & & $\begin{array}{l}\text { 1-Not intense } \\
\text { 7-Very intense }\end{array}$ \\
\hline Malty porridge aroma & $\begin{array}{l}\text { Intensity of aroma } \\
\text { associated with malted finger millet }\end{array}$ & $\begin{array}{l}\text { 7-Aroma of malted finger millet after } \\
2 \text { days of malting Snapping variety }\end{array}$ & $\begin{array}{l}\text { 1-Not intense malty aroma } \\
\text { 7-Strong malty aroma }\end{array}$ \\
\hline Cooked cowpea aroma & $\begin{array}{c}\text { Intensity of aroma } \\
\text { associated with cooked cowpea }\end{array}$ & $\begin{array}{l}\text { 7-Aroma of boiled whole cowpea } \\
\text { (Boiled for } 60 \mathrm{~min} \text { in excess water) }\end{array}$ & $\begin{array}{l}\text { 1-Low cooked cowpea aroma } \\
\text { 7-Strong cooked cowpea aroma }\end{array}$ \\
\hline Finger millet aroma & $\begin{array}{l}\text { Intensity of aroma } \\
\text { associated with millet }\end{array}$ & $\begin{array}{l}7 \text {-Aroma of finger millet } \\
\text { porridge with } 25 \% \text { solids }\end{array}$ & $\begin{array}{l}\text { 1-Not intense finger millet aroma } \\
\text { 7-Strong finger millet aroma }\end{array}$ \\
\hline \multicolumn{4}{|c|}{ Texture } \\
\hline Coarseness & $\begin{array}{l}\text { Extend to which grittiness or granules } \\
\text { of porridge caused by small particles }\end{array}$ & & $\begin{array}{l}\text { 1-Not coarse } \\
\text { 7-Very coarse }\end{array}$ \\
\hline Viscosity & $\begin{array}{l}\text { Force required to draw a liquid } \\
\text { from a spoon over the tongue }\end{array}$ & $\begin{array}{l}\text { 7-Thickness of Finger } \\
\text { millet porridge with } 25 \% \text { solids }\end{array}$ & $\begin{array}{l}\text { 1-Thin } \\
\text { 7-Thick }\end{array}$ \\
\hline Stickiness & $\begin{array}{l}\text { Ability of porridge to stick } \\
\text { on the wall of glass }\end{array}$ & & $\begin{array}{l}\text { 1-Less sticky } \\
\text { 7-Too sticky }\end{array}$ \\
\hline \multicolumn{4}{|c|}{ Flavour } \\
\hline Overall Flavour intensity & $\begin{array}{l}\text { Overall flavour intensity } \\
\text { of the porridge }\end{array}$ & & $\begin{array}{l}\text { 1-Not intense } \\
\text { 7-Strong intense }\end{array}$ \\
\hline Cooked cowpea flavour & $\begin{array}{l}\text { Intensity of the flavour } \\
\text { of cooked cowpea }\end{array}$ & $\begin{array}{l}\text { 7-Flavour of boiled whole cowpea } \\
\text { (Boiled for } 60 \mathrm{~min} \text { in excess water) }\end{array}$ & $\begin{array}{l}\text { 1-Less cooked cowpea flavour } \\
\text { 7-Strong cooked cowpea flavour }\end{array}$ \\
\hline Millet flavour & $\begin{array}{l}\text { Intensity of flavour of } \\
\text { cooked raw finger millet }\end{array}$ & $\begin{array}{l}7 \text { Flavour of finger millet } \\
\text { porridge with } 25 \% \text { solids }\end{array}$ & $\begin{array}{l}\text { 1-Not intense } \\
7 \text {-Very intense }\end{array}$ \\
\hline Malty flavour & $\begin{array}{l}\text { Intensity of flavour of cooked } \\
\text { malted finger millet }\end{array}$ & $\begin{array}{l}\text { 7-Flavour of malted finger millet after } \\
2 \text { days of malting Snapping variety }\end{array}$ & $\begin{array}{l}\text { 1-Not intense } \\
\text { 7-Very intense }\end{array}$ \\
\hline Burnt flavour & $\begin{array}{l}\text { Intensity of flavour of porridge } \\
\text { associated with burnt porridge residues }\end{array}$ & $\begin{array}{l}\text { 7-Flavour malted finger millet } \\
\text { porridge having } 25 \% \text { solids burnt } \\
\text { during preparations }\end{array}$ & $\begin{array}{l}\text { 1-Not intense } \\
7 \text {-Very intense }\end{array}$ \\
\hline \multicolumn{4}{|c|}{ Sensation after swallowing the sample (Aftertaste) } \\
\hline Malty aftertaste & $\begin{array}{l}\text { Intensity of cooked malted finger } \\
\text { millet porridge flavour perceived } \\
\text { in the mouth after swallowing }\end{array}$ & $\begin{array}{l}\text { 7-Aftertaste of malted finger } \\
\text { millet after } 2 \text { days of malting } \\
\text { Snapping variety }\end{array}$ & $\begin{array}{l}\text { 1-Not intense } \\
7 \text {-Very intense }\end{array}$ \\
\hline Cowpea aftertaste & $\begin{array}{c}\text { Intensity of cooked cowpea flavour } \\
\text { perceived in the mouth after swallowing }\end{array}$ & $\begin{array}{l}\text { 7-Aftertaste of boiled whole cowpea } \\
\text { (Boiled for } 60 \mathrm{~min} \text { in excess water) }\end{array}$ & $\begin{array}{l}\text { 1-Not intense } \\
7 \text {-Very intense }\end{array}$ \\
\hline Millet after taste & $\begin{array}{l}\text { Intensity of aftertaste associated with } \\
\text { cooked millet porridge perceived after } \\
\text { swallowing porridge }\end{array}$ & $\begin{array}{l}\text { 7-Aftertaste of finger millet } \\
\text { porridge with } 25 \% \text { solids }\end{array}$ & $\begin{array}{l}\text { 1-Not intense } \\
7 \text {-Very intense }\end{array}$ \\
\hline Astringency & $\begin{array}{l}\text { Dry feeling in the mouth } \\
\text { after swallowing }\end{array}$ & & $\begin{array}{l}\text { 1-Not intense } \\
7 \text {-Very intense }\end{array}$ \\
\hline Presence of residue & $\begin{array}{l}\text { Leaves particles of the } \\
\text { grain in mouth and teeth }\end{array}$ & & $\begin{array}{l}\text { 1-Low } \\
\text { 7-High }\end{array}$ \\
\hline
\end{tabular}


Descriptive sensory evaluation of Porridge

Composite flour (100 g) was mixed with 200-mL cold water to form a thick batter. Water $(350 \mathrm{~mL})$, was brought to boil and then the batter added with continuous stirring using a cooking stick until the mixture formed a viscous gruel. The porridge was steamed on low heat for $10 \mathrm{~min}$ The porridge was then placed in well labelled different jars, and then maintained at $50^{\circ} \mathrm{C}$ in a water bath, to keep the porridge warm for descriptive sensory evaluation.

Cooked porridge (50-mLportions) was served in glass ramekins kept warm in a water bath at $50^{\circ} \mathrm{C}$. The sensory evaluation of the porridge was conducted in a sensory evaluation room with individual booths. Panelists evaluated all samples in duplicate. Each panellist received six samples of porridge on glass ramekins, a serviette and a plastic disposable cup filled with filtered tap water for rinsing the mouth before and between tasting the samples. To avoid fatigue, three samples were tasted and after a 10 min break, the other three samples kept warm in a water bath at $50^{\circ} \mathrm{C}$, were tasted. The order of sample presentation of the samples was randomised for each panel. Seventeen descriptive terms, were used by the panellists, grouped under flavour, aroma, texture and aftertaste attributes as represented in Table 1. Aroma was first to be evaluated using short sniffs. Thereafter, a full spoon of the porridge was chewed in the mouth for texture and flavour testing. Aftertaste properties were analysed by the panellists after swallowing the porridge. Table 1 shows the definitions of the terms developed by the panellists. A seven-point line scale was used to measure the intensity of each attribute for a given sample. The minimum value was one denoting not perceived, not coarse or not thick. The maximum point was seven denoting strongly perceived, very coarse or very thick.

\subsection{Statistical Data Analysis}

The effects of malting finger millet, compositing and cooking on the anti-nutrient content and sensory properties of the complementary porridge were evaluated using analysis of variance (ANOVA) based on a 5\% level of significance. Significant differences between means were determined using Tukey's honestly significance difference (HSD). Calculations were performed using Statistical Analysis System (SAS) version 9.3 at $\mathrm{p}<0.05$. Furthermore, principal component analysis (PCA) was performed to study sample relationships.

\section{Results and Discussion}

\subsection{Effect of Compositing Malted Finger Millet Flour with Precooked Cowpea on Total Phenols of Baby-Weaning Food}

\section{Effect of malting finger millet on total phenol of complementary porridge}

Unmalted KNE 741 (control), had the highest amount of total phenols (condensed tannins, flavonoids and phenolic acids) at $2.32 \mathrm{mg} \mathrm{CE} / 100 \mathrm{mg}$, (db) as compared to unmalted Snapping (control) at $1.26 \mathrm{mg} \mathrm{CE} \mathrm{/100} \mathrm{mg} \mathrm{(db)} \mathrm{(Table}$ 2 ). They were significantly different at $\mathrm{p}<0.05$, denoting varietal influence in 
Table 2. Effects of compositing precooked cowpea with improved malted finger millet on phenol content of finger millet complementary porridge.

\begin{tabular}{|c|c|c|c|c|c|c|c|c|c|}
\hline \multirow[b]{3}{*}{ Millet variety } & \multirow[b]{3}{*}{ Composite } & \multicolumn{4}{|c|}{ Condensed tannins as mg CE/100 mg, $(\mathrm{db})$} & \multicolumn{4}{|c|}{ Total Phenols as mg CE/100 mg, (db) } \\
\hline & & \multicolumn{2}{|c|}{ Flour } & \multicolumn{2}{|c|}{ Porridge } & \multicolumn{2}{|c|}{ Flour } & \multicolumn{2}{|c|}{ Porridge } \\
\hline & & $\begin{array}{l}\text { Unmalted } \\
+ \text { Cowpea }\end{array}$ & $\begin{array}{c}\text { Malted } \\
+ \text { Cowpea }\end{array}$ & $\begin{array}{l}\text { Unmalted } \\
+ \text { Cowpea }\end{array}$ & $\begin{array}{c}\text { Malted } \\
+ \text { Cowpea }\end{array}$ & $\begin{array}{l}\text { Unmalted } \\
+ \text { Cowpea }\end{array}$ & $\begin{array}{c}\text { Malted } \\
+ \text { Cowpea }\end{array}$ & $\begin{array}{l}\text { Unmalted } \\
+ \text { Cowpea }\end{array}$ & $\begin{array}{c}\text { Malted } \\
+ \text { Cowpea }\end{array}$ \\
\hline \multirow[t]{7}{*}{ Snapping } & $0 \%$ (Control) & $0.61^{\mathrm{fg}} \pm 0.06$ & $0.34^{\mathrm{h}} \pm 0.04$ & $0.61^{\mathrm{e}} \pm 0.03$ & $0.35^{\mathrm{fh}} \pm 0.00$ & $1.26^{\mathrm{i}} \pm 0.09$ & $0.83^{\mathrm{h}} \pm 0.03$ & $1.09^{\mathrm{b}} \pm 0.03$ & $1.07^{\mathrm{b}} \pm 0.09$ \\
\hline & $10.34 \%$ PKS & $0.62^{\mathrm{f}} \pm 0.06$ & $0.35^{\mathrm{gh}} \pm 0.02$ & $0.62^{\mathrm{e}} \pm 0.04$ & $0.33^{\mathrm{h}} \pm 0.03$ & $1.44^{\mathrm{k}} \pm 0.03$ & $1.30^{c} \pm 0.05$ & $1.03^{\text {cd }} \pm 0.03$ & $1.01^{\mathrm{c}} \pm 0.09$ \\
\hline & $21.26 \%$ PKS & $0.56^{\mathrm{h}} \pm 0.04$ & $0.37^{\mathrm{f}} \pm 0.06$ & $0.56^{\mathrm{f}} \pm 0.02$ & $0.38^{\mathrm{ef}} \pm 0.05$ & $1.50^{\mathrm{j}} \pm 0.00$ & $1.22^{\mathrm{e}} \pm 0.05$ & $0.92^{\mathrm{e}} \pm 0.05$ & $0.87^{\mathrm{e}} \pm 0.26$ \\
\hline & $32.75 \%$ PKS & $0.53^{\mathrm{i}} \pm 0.02$ & $0.40^{\mathrm{e}} \pm 0.04$ & $0.53^{\mathrm{g}} \pm 0.03$ & $0.39^{e} \pm 0.05$ & $1.54^{\mathrm{i}} \pm 0.03$ & $1.10^{\mathrm{g}} \pm 0.03$ & $0.85^{\mathrm{f}} \pm 0.04$ & $0.80^{\mathrm{f}} \pm 0.11$ \\
\hline & $10.34 \% \mathrm{PKF}$ & $0.59^{g} \pm 0.06$ & $0.33^{\mathrm{h}} \pm 0.09$ & $0.55^{\mathrm{g}} \pm 0.05$ & $0.33^{\mathrm{h}} \pm 0.06$ & $1.76^{\mathrm{g}} \pm 0.03$ & $1.49^{\mathrm{b}} \pm 0.09$ & $1.05^{\mathrm{c}} \pm 0.08$ & $1.00^{c} \pm 0.10$ \\
\hline & $21.26 \% \mathrm{PKF}$ & $0.55^{\mathrm{hi}} \pm 0.02$ & $0.32^{\mathrm{h}} \pm 0.03$ & $0.46^{\mathrm{h}} \pm 0.04$ & $0.34^{\mathrm{fh}} \pm 0.07$ & $1.70^{\mathrm{h}} \pm 0.03$ & $1.23^{\mathrm{e}} \pm 0.07$ & $1.13^{\mathrm{a}} \pm 0.00$ & $1.11^{\mathrm{a}} \pm 0.27$ \\
\hline & $32.75 \%$ PKF & $0.50^{j} \pm 0.03$ & $0.32^{\mathrm{h}} \pm 0.11$ & $0.47^{\mathrm{h}} \pm 0.07$ & $0.36^{\mathrm{f}} \pm 0.00$ & $1.68^{\mathrm{h}} \pm 0.03$ & $1.17^{\mathrm{f}} \pm 0.07$ & $1.11^{\mathrm{ab}} \pm 0.03$ & $1.02^{\mathrm{c}} \pm 0.19$ \\
\hline \multirow[t]{7}{*}{ KNE741 } & $0 \%$ (Control) & $1.27^{\mathrm{a}} \pm 0.02$ & $0.64^{\mathrm{b}} \pm 0.02$ & $1.11^{\mathrm{a}} \pm 0.03$ & $0.62^{\mathrm{b}} \pm 0.03$ & $2.32^{\mathrm{a}} \pm 0.05$ & $1.36^{c} \pm 0.05$ & $1.00^{\mathrm{d}} \pm 0.03$ & $0.92^{\mathrm{d}} \pm 0.03$ \\
\hline & $10.34 \%$ PKS & $1.11^{\mathrm{c}} \pm 0.05$ & $0.69^{\mathrm{a}} \pm 0.03$ & $1.00^{\mathrm{b}} \pm 0.04$ & $0.62^{\mathrm{b}} \pm 0.02$ & $2.24^{\mathrm{b}} \pm 0.05$ & $1.71^{\mathrm{a}} \pm 0.09$ & $1.14^{\mathrm{a}} \pm 0.03$ & $1.09^{\mathrm{ab}} \pm 0.03$ \\
\hline & $21.26 \%$ PKS & $0.98^{\mathrm{d}} \pm 0.04$ & $0.64^{\mathrm{b}} \pm 0.03$ & $0.94^{c} \pm 0.03$ & $0.61^{b c} \pm 0.02$ & $2.10^{\mathrm{d}} \pm 0.03$ & $1.47^{\mathrm{b}} \pm 0.19$ & $1.04^{\mathrm{c}} \pm 0.05$ & $1.02^{c} \pm 0.03$ \\
\hline & $32.75 \%$ PKS & $0.84^{\mathrm{e}} \pm 0.07$ & $0.59^{c} \pm 0.10$ & $0.76^{d} \pm 0.03$ & $0.59^{c} \pm 0.00$ & $2.09^{\mathrm{d}} \pm 0.09$ & $1.28^{\mathrm{d}} \pm 0.05$ & $0.94^{\mathrm{e}} \pm 0.03$ & $0.93^{\mathrm{d}} \pm 0.05$ \\
\hline & 10.34\% PKF & $1.15^{\mathrm{b}} \pm 0.06$ & $0.65^{\mathrm{b}} \pm 0.03$ & $0.94^{c} \pm 0.03$ & $0.65^{\mathrm{a}} \pm 0.02$ & $2.16^{c} \pm 0.09$ & $1.33^{\mathrm{c}} \pm 0.05$ & $1.03^{\mathrm{cd}} \pm 0.12$ & $1.03^{\mathrm{c}} \pm 0.03$ \\
\hline & 21.26\% PKF & $0.96^{\mathrm{d}} \pm 0.03$ & $0.61^{c} \pm 0.03$ & $1.12^{\mathrm{a}} \pm 0.04$ & $0.60^{\mathrm{bc}} \pm 0.03$ & $2.01^{\mathrm{e}} \pm 0.04$ & $1.33^{c} \pm 0.07$ & $0.88^{\mathrm{f}} \pm 0.03$ & $0.87^{\mathrm{e}} \pm 0.05$ \\
\hline & 32.75\% PKF & $0.86^{\mathrm{e}} \pm 0.04$ & $0.56^{\mathrm{d}} \pm 0.02$ & $0.77^{\mathrm{d}} \pm 0.04$ & $0.54^{\mathrm{d}} \pm 0.04$ & $1.97^{\mathrm{f}} \pm 0.03$ & $1.28^{\mathrm{d}} \pm 0.05$ & $0.98^{\mathrm{d}} \pm 0.03$ & $1.00^{c} \pm 0.03$ \\
\hline
\end{tabular}

Values are means \pm standard deviations. Values of a parameter in a column, followed by different superscript letters are significantly different at $\mathrm{p} \leq 0.05, \mathrm{n}$ = 3, PKS-Precooked KundeSoko, PKF-Precooked KundeFaulu, CE-Catechin equivalent, db-dry weight basis.

the phenol content of the finger millet varieties. Polyphenols act as anti-feedants, phytoalexins, contributors to plant pigmentation and antioxidants therefore they have an important role in cereals such as finger millet and sorghum [22]. This explains the high levels observed in these two varieties of finger millet. In addition, because of their astringency especially condensed tannins, they are able to reduce bird damage during immature stages of crop growth, thus they play a critical role in plant growth. However, these positive agronomic attributes of polyphenols are accompanied by nutritional disadvantages to consumers especially infants, as they bind to protein reducing protein bioavailability. After malting, there was a significant $(\mathrm{p}<0.05)$ reduction of total phenols in the two finger millet varieties (Table 2). An approximately $9 \%$ to $41 \%$ reduction in phenol was evidenced and it was similar to what has been reported in literatureSingh and Raghuvanshi [23]. Malted KNE741 showed a substantial reduction as compared to snapping variety. This reduction in polyphenols can be attributed to number reasons. First, there could be leaching of water-soluble compounds especially the free bound phenolic acids. Secondly, there could also be formation of insoluble complexes of phenolic compounds especially with dietary protein contributes to this reduction. Lastly, breakdown of condensed tannins to lower molecular compound through the action of inherent hydrolytic 
enzyme polyphenol oxidase may contribute to further reduction.

Effect of compositing malted finger millet with precooked cowpea on total phenols of complementary porridge

Addition of precooked cowpea, which had low amount of phenols, trypsin inhibitors and other anti-nutrients greatly, significantly $(\mathrm{p}<0.05)$ influenced reduction of assayable phenols in the composites. This is illustrated by the high reduction in phenols of approximately $40 \%$ as compared to snapping at $0 \%$ (100\% malted finger millet when malted snapping finger millet variety was composited with cowpea at $32.75 \%$, (Table 2).

The effect of cooking malted finger millet with precooked cowpea on total phenols of complementary porridge

Cooking resulted in significant $(\mathrm{p}<0.05)$ reduction of phenol content of up to $8 \%$ in extractable phenol of the composite flours. This is probably due to structural binding of phenols to other macromolecules during cooking resulted in low assayable phenols. Chemical nature of the phenolic compounds, sample particle size, extraction methods and the assay method itself also influenced assayable phenols. The method used involved reduction-oxidation reaction during which at basic $\mathrm{pH}$, the phenolate ion is oxidised, while phosphotungstic/phospho-molybdic acid complex reduced to chromogens (blue coloured solution) [24]. Therefore, assayable phenols may have decreased either through interference of reducing substances or apparent binding of phenols to other macromolecules such as protein at a basic $\mathrm{pH}$ during cooking of the complementary porridge.

\subsection{Effect of Compositing Malted Finger Millet Flour with Precooked Cowpea on Condensed Tannins of Baby-Weaning Food}

Effect of malting finger millet on condensed tannins of complementary porridge

KNE741 (0\%), had the highest amount of tannins, which was significantly different at $\mathrm{p}<0.05$ from Snapping ( $0 \%$ control) (Table 2). This also explains influence of variety on condensed tannins of finger millet varieties. Tannins are located mostly in the testa, and their occurrences are influenced by finger millet variety [9]. These authors working on different finger millet varieties concluded that finger millet comprising of thick testa had a significant amount of tannins as compared to those with thin testa and they help protect finger millet grain against birds, insects, and fungal attack. This possibly, explains the difference in tannin content of the two varieties. Condensed tannins are able to form indigestible protein-tannin complex, via hydrophobic interactions and hydrogen bonding. Finger millet prolamins (eleusinin) just like sorghum kafirins are proline-rich, therefore, they are able to strongly bind with protein reducing protein digestibility as reviewed by [13]. Table 2 shows that there is a significant ( $p$ $<0.05$ ) reduction of up to approximately $40 \%$ in tannin content after malting the two finger millet varieties. Reduction in tannin after malting has widely been 
reported in literature [23]. Hejazi and Orst [25], working with finger millet malted at different durations $(24 \mathrm{~h}, 48 \mathrm{~h}$ and $72 \mathrm{~h}$ ) were able to show a positive reduction between tannin content and germination duration. The reduction is mainly attributed to steeping step of the finger millet grains. During steeping, there is leaching of tannin into the sprouting medium [15], also during malting, tannin reduction is hypothesized to be reduced via high activity of polyphenol oxidase that hydrolyses tannin molecule into lower molecular weight compounds, flavanols [26]. It is therefore of importance that, reduction in condensed tannins will result in low formation of indigestible protein-tannin complexes. In addition the low molecular weight compounds formed (flavanols), after breakdown of condensed tannins, are unable to exert stearic effects to proteins and in process would result in increase in protein quality.

Effect of compositing malted finger millet with precooked cowpea on condensed tannins of complementary porridge

Compositing resulted in approximately $21 \%$ reduction in condensed tannins when unmalted finger millet was composited with precooked cowpea at $10.34 \%$, $21.26 \%$ and $32.75 \%$ levels. It had also a compound effect when malted finger millet was composited with precooked cowpea as it resulted in $18 \%$ reduction in condensed tannins. The reduction was attributed to addition of precooked cowpea that had low amount of tannins as compared to uncooked cowpea. Also, malting of finger millet resulted in low amount of tannins in the composites as discussed above resulting in low amount assayable condensed tannins in the composites formulated.

Effect of cooking malted finger millet with precooked cowpea on condensed tannins of complementary porridge

Cooking of the complementary foods resulted in significant $(\mathrm{p}<0.05)$ decrease in assayable tannin content by approximately between $22 \%$ and $47 \%$ (Table 2). This is in agreement with previous studies. For example, Anyango et al. [13], working with compositing of sorghum foods with cowpea, observed a substantial tannin reduction of between $18 \%$ and $69 \%$. Hypotheses, surrounding these reductions include; structural organization of tannins resulting in interaction of tannins with other grain components such as carbohydrates and protein, forming less extractable complexes [27], therefore lowering tannin assayed in the complementary foods. Secondly, during cooking of the porridges there is thermally induced degradation [28], of tannins, resulting into simpler flavanol compounds as seen in sorghum tannin. There were inconsistences in some of the tannin values for the cooked porridge flours as compared to the raw composite flour. These apparent inconsistences may be explained due to the principle behind Vanillin-HCl method, which is specific to dihydrochalcones, flavan-3-ols and proanthocyanidins, because of single bond they possess at 2, 3-position and a free hydroxy group as reviewed by [22]. The shortcoming with this assay method is that, it is more sensitive to polymeric proanthocyanidins rather than monomeric flavan-3 ols. During cooking assayable tannins may have decreased due to binding of leuco-anthocyanidins to macromolecules such as protein or 
depolymerisation, degradation and polymerization of the proanthocyanidins [29].

\subsection{Effect of Compositing Malted Finger Millet Flour with Precooked Cowpea on Phytic Acid Content of Baby-Weaning Food}

\section{Effect of malting finger millet on phytic acid of complementary porridge}

Snapping (control) showed a significant $(\mathrm{p}<0.05)$ higher amount of phytate as compared to KNE741 (Control) variety, showing that variety had a significant effect on phytic acid in the grains [30] (Table 3). The high values seen for phytate in the unmalted samples are attributed to area where they were grown. The environment was characterized with high temperatures and low rainfall, which have great influence on phytic acid synthesis. Phytic acid synthesis involves enzyme myo-inositol-3-phosphate synthase (MIPS), which converts D-glucose to myo-inositol phosphate, later undergoes various phosphorylations steps to form phytic acid. Optimum temperature for MIPS activity in plants is $35^{\circ} \mathrm{C}$ and a $\mathrm{pH}$, of between 7.0 and 7.5 [31]. These conditions therefore are responsible for high phytate levels in the unmalted grains. After malting, MKNE741 showed a significant $(\mathrm{p}<0.05)$, reduction of phytate by an approximately $44 \%$ (Table 3 ). Malting also significantly $(\mathrm{p}<0.05)$ reduced phytate in the composites made from malted finger millet by approximately between $12 \%$ and $44 \%$ in Table 3 . This is due to increment in endogenous phytatase which significantly degraded phytate into inorganic phosphorous and inositol [32]. In the present study the apparent decrease was lower as compared to reported values by Traoré et al., [32] at $67 \%$. The difference is probably due to different assay used in analysis.

Table 3. Effects of compositing precooked cowpea with improved malted finger millet on Phytic acid content of finger millet complementary porridge as Phytate $\mathrm{P} \mathrm{mg} / 100 \mathrm{~g}(\mathrm{db})$.

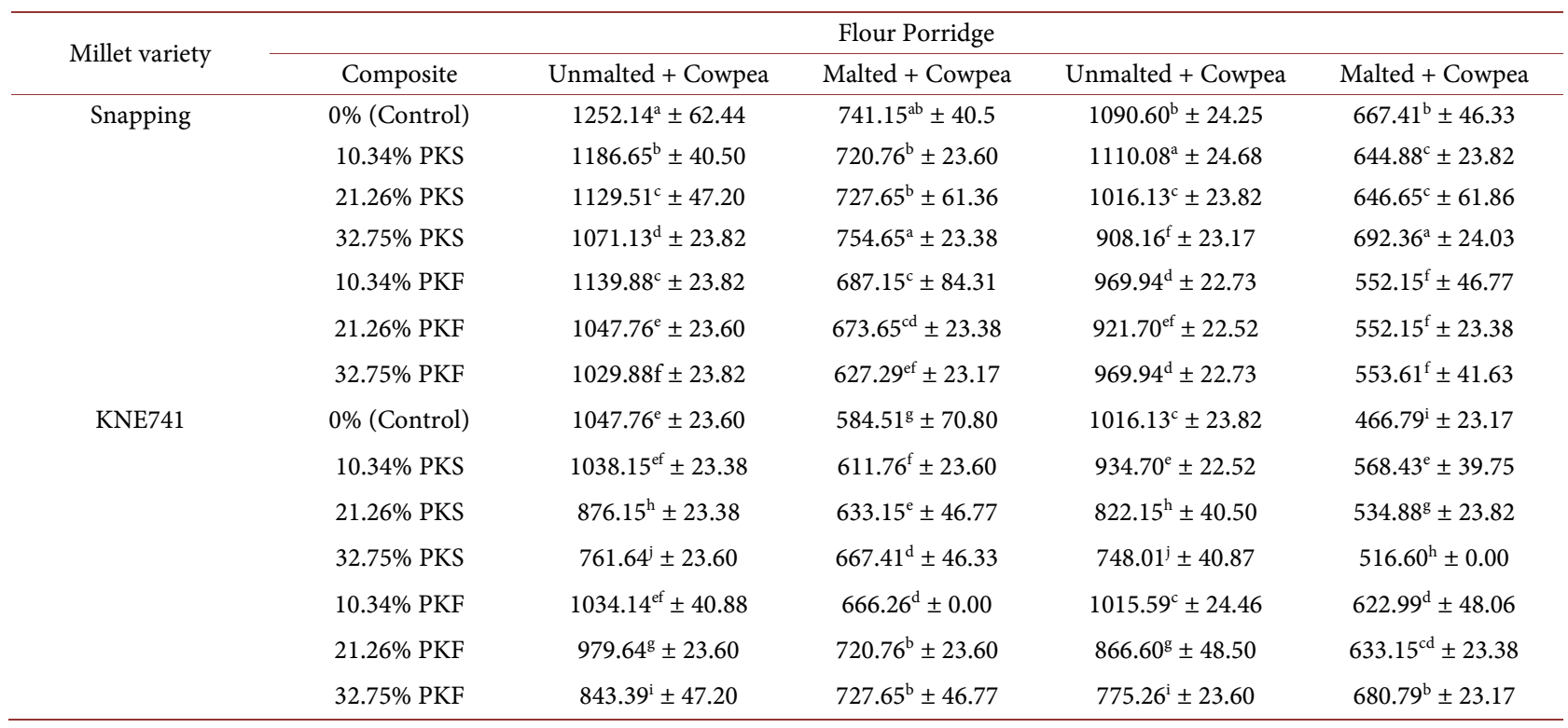

Values are means \pm standard deviations. Values of a parameter in a column, followed by different superscript letters are significantly different at $\mathrm{p} \leq 0.05$, $\mathrm{n}$ = 3, PKS-Precooked Kundesoko, PKF-Precooked Kundefaulu, db-dry weight basis. 
Effect of compositing malted finger millet with precooked cowpea on phytic acid of complementary porridge

When unmalted Snapping was composited with precooked cowpea it showed significant $(\mathrm{p}<0.05)$ higher values of phytate as compared to KNE741. Unmalted KNE741 composited with precooked Kundesoko (PKS) at $32.75 \%$ had lowest amount of phytate. Compositing with precooked cowpea resulted in significant $(\mathrm{p}<0.05)$ reduction of phytate by factor of $72 \%$ (Table 3 ), because precooked cowpea has low amount of phytate (since there is leaching of phytate into cooking liquor during cowpea cooking process).

Effect of cooking malted finger millet with precooked cowpea on phytic acid of complementary porridge

Cooking resulted in $6 \%$ and $20 \%$ reduction of phytate in the complementary baby foods (Table 3). This apparent low phytate values of the composite flours; maybe due to structural binding of phytates to other cell components due to the fact that phytic acid is a strong chelating agent of minerals, proteins and other macromolecules [31]. Therefore during cooking, maybe heat was a strong promoter of chelation between phytate and other macromolecules reducing assayable phyatates.

\subsection{Effect of Compositing Malted Finger Millet Flour with Precooked Cowpea on Sensory Attributes of Baby-Weaning Food}

Effect of malting finger millet on sensory quality of complementary porridge

F-values from the analysis of variance showed a significance difference $(\mathrm{p}<$ $0.05)$ for all the 17 sensory attributes of the complementary porridge (Table 4), indicating the panellists were able to differentiate porridge prepared from malted finger millet composited with precooked cowpea. There was a significance difference in texture attributes (coarseness, stickiness and viscosity) and astringency aftertaste at $\mathrm{p}<0.05$ between the unmalted and malted complementary porridge, with the former, showing a high intensity for the above four attributes. During malting, there is an accompanying effect on texture attributes sensory attributes. Since hydrolytic enzymes are to break large molecules especially starch, reducing amount available for gelatinization, resulted in porridge that are less viscous, this explains the difference in between malted and unmalted complementary porridges. Astringent is defined as the hard, constricting sensation felt in the mouth tissues as one is taking the porridge. This is mostly caused by the high levels of bitter and strong tannins and polyphenols Awika et al. [28], which are found in unmalted millet flour. As the millet is malted the level of tannins and polyphenols reduces due to the action of the enzyme phytase activated in malting conditions, explains the low values exhibited by malted complementary porridge.

Effect of adding precooked cowpea flour on sensory quality of complementary porridge 
Table 4. Effects of compositing precooked cowpea with improved malted finger millet on sensory attributes of finger millet complementary porridge.

\begin{tabular}{|c|c|c|c|c|c|c|c|c|c|c|c|c|}
\hline \multirow[b]{2}{*}{ Composite } & \multicolumn{4}{|c|}{ Aroma } & \multicolumn{3}{|c|}{ Texture } & \multicolumn{5}{|c|}{ Flavour } \\
\hline & $\begin{array}{c}\text { Overall } \\
\text { intensity }\end{array}$ & Malty & $\begin{array}{l}\text { cooked } \\
\text { cowpea }\end{array}$ & finger millet & Coarseness & Viscosity & Stickiness & $\begin{array}{l}\text { Overall } \\
\text { flavour }\end{array}$ & $\begin{array}{l}\text { Cooked } \\
\text { cowpea }\end{array}$ & finger millet & Malty & Burnt \\
\hline $\begin{array}{c}\text { KNE741 } \\
(0 \%)\end{array}$ & $1.4^{\mathrm{f}} \pm 0.55$ & $1.20^{\mathrm{g}} \pm 0.45$ & $2.0^{\mathrm{f}} \pm 0.71$ & $4.8^{\mathrm{c}} \pm 0.45$ & $5.6^{\mathrm{b}} \pm 0.89$ & $7.0^{a} \pm 0.00$ & $7.0^{\mathrm{a}} \pm 0.00$ & $2.8^{\mathrm{e}} \pm 0.84$ & $1.8^{\mathrm{g}} \pm 0.45$ & $6.0^{b} \pm 0.71$ & $1.4^{\mathrm{h}} \pm 0.89$ & $1.0^{g} \pm 0.00$ \\
\hline $\begin{array}{l}\text { KNE741 } \\
(21.26 \%)\end{array}$ & $1.4^{\mathrm{f}} \pm 0.55$ & $1.20^{\mathrm{g}} \pm 0.45$ & $4.4^{\mathrm{c}} \pm 1.14$ & $4.0^{\mathrm{e}} \pm 1.41$ & $3.4^{e} \pm 0.55$ & $7.0^{\mathrm{a}} \pm 0.00$ & $7.0^{\mathrm{a}} \pm 0.00$ & $4.0^{\mathrm{d}} \pm 0.71$ & $4.8^{\mathrm{d}} \pm 0.45$ & $4.6^{c} \pm 1.34$ & $1.4^{\mathrm{h}} \pm 0.89$ & $1.2^{\mathrm{g}} \pm 0.45$ \\
\hline $\begin{array}{l}\text { KNE741 } \\
(32.75 \%)\end{array}$ & $2.4^{\mathrm{e}} \pm 1.34$ & $1.8^{\mathrm{f}} \pm 0.84$ & $4.6^{c} \pm 0.89$ & $4.6^{\mathrm{cd}} \pm 0.55$ & $4.8^{c} \pm 1.10$ & $6.6^{\mathrm{b}} \pm 0.55$ & $6.6^{\mathrm{b}} \pm 0.55$ & $1.8^{\mathrm{f}} \pm 0.45$ & $6.0^{\mathrm{a}} \pm 1.22$ & $4.0^{\mathrm{d}} \pm 0.71$ & $3.8^{\mathrm{e}} \pm 0.84$ & $3.6^{\mathrm{cd}} \pm 0.89$ \\
\hline $\begin{array}{c}\text { MKNE741 } \\
(0 \%)\end{array}$ & $1.4^{\mathrm{f}} \pm 0.55$ & $5.8^{\mathrm{b}} \pm 1.10$ & $4.2^{\mathrm{cd}} \pm 1.10$ & $4.6^{\mathrm{cd}} \pm 0.89$ & $3.8^{\mathrm{de}} \pm 1.10$ & $2.0^{\mathrm{g}} \pm 0.00$ & $3.0^{\mathrm{d}} \pm 1.00$ & $5.6^{\mathrm{b}} \pm 0.89$ & $3.6^{\mathrm{ef}} \pm 0.55$ & $3.8^{\mathrm{d}} \pm 1.10$ & $6.6^{a} \pm 0.55$ & $4.6^{\mathrm{a}} \pm 1.14$ \\
\hline $\begin{array}{c}\text { MKNE741 } \\
(21.26 \%)\end{array}$ & $5.4^{\mathrm{b}} \pm 1.52$ & $5.2^{c} \pm 0.84$ & $5.6^{a} \pm 0.89$ & $4.4^{\mathrm{d}} \pm 0.89$ & $3.4^{\mathrm{e}} \pm 0.89$ & $2.4^{f} \pm 0.89$ & $1.4^{\mathrm{f}} \pm 0.55$ & $4.8^{\mathrm{cd}} \pm 1.10$ & $3.4^{\mathrm{f}} \pm 0.55$ & $4.4^{\mathrm{cd}} \pm 0.89$ & $5.6^{\mathrm{b}} \pm 0.89$ & $3.8^{\mathrm{c}} \pm 1.10$ \\
\hline $\begin{array}{c}\text { SNAPP } \\
(0 \%)\end{array}$ & $5.4^{\mathrm{b}} \pm 1.34$ & $2.4^{\mathrm{e}} \pm 0.89$ & $4.4^{c} \pm 0.55$ & $6.0^{a} \pm 0.00$ & $4.6^{\mathrm{cd}} \pm 0.89$ & $6.8^{\mathrm{ab}} \pm 0.45$ & $7.0^{\mathrm{a}} \pm 0.00$ & $4.8^{\mathrm{cd}} \pm 1.10$ & $2.0^{\mathrm{g}} \pm 0.00$ & $6.8^{\mathrm{a}} \pm 0.45$ & $2.6^{\mathrm{g}} \pm 0.89$ & $2.6^{e} \pm 0.89$ \\
\hline $\begin{array}{l}\text { SNAPP } \\
(21.26 \%)\end{array}$ & $4.0^{\mathrm{d}} \pm 0.71$ & $2.6^{e} \pm 0.89$ & $3.2^{\mathrm{e}} \pm 0.84$ & $5.6^{\mathrm{b}} \pm 0.55$ & $6.0^{\mathrm{a}} \pm 1.0$ & $6.6^{\mathrm{b}} \pm 0.55$ & $6.4^{b} \pm 0.55$ & $3.6^{\mathrm{d}} \pm 0.55$ & $3.8^{\mathrm{e}} \pm 0.45$ & $6.0^{\mathrm{b}} \pm 0.71$ & $3.2^{\mathrm{f}} \pm 0.45$ & $1.8^{\mathrm{f}} \pm 0.45$ \\
\hline $\begin{array}{l}\text { SNAPP } \\
(32.75 \%)\end{array}$ & $3.8^{\mathrm{d}} \pm 1.30$ & $3.4^{\mathrm{d}} \pm 0.55$ & $5.0^{b} \pm 0.71$ & $5.6^{\mathrm{b}} \pm 0.55$ & $4.6^{\mathrm{cd}} \pm 0.89$ & $6.2^{c} \pm 1.10$ & $5.6^{c} \pm 0.89$ & $5.6^{\mathrm{b}} \pm 0.55$ & $5.6^{\mathrm{b}} \pm 0.55$ & $4.8^{\mathrm{c}} \pm 0.45$ & $3.8^{\mathrm{e}} \pm 0.45$ & $3.6^{\mathrm{cd}} \pm 0.55$ \\
\hline $\begin{array}{c}\text { MSNAPP } \\
(0 \%)\end{array}$ & $6.0^{\mathrm{a}} \pm 1.00$ & $5.8^{\mathrm{b}} \pm 0.84$ & $3.6^{\mathrm{de}} \pm 0.89$ & $3.6^{\mathrm{f}} \pm 0.55$ & $2.4^{\mathrm{f}} \pm 0.45$ & $2.2^{\mathrm{fg}} \pm 0.45$ & $2.0^{\mathrm{e}} \pm 0.00$ & $6.2^{\mathrm{a}} \pm 0.89$ & $1.8^{\mathrm{g}} \pm 0.55$ & $3.6^{\mathrm{de}} \pm 0.55$ & $6.6^{\mathrm{a}} \pm 0.55$ & $4.4^{\mathrm{ab}} \pm 0.89$ \\
\hline $\begin{array}{c}\text { MSNAPP } \\
(21.26 \%)\end{array}$ & $5.8^{\mathrm{ab}} \pm 0.45$ & $6.2^{\mathrm{a}} \pm 0.84$ & $3.4^{\mathrm{de}} \pm 0.89$ & $4.0^{\mathrm{e}} \pm 0.71$ & $4.2^{\mathrm{d}} \pm 1.30$ & $1.8^{\mathrm{g}} \pm 0.45$ & $1.6^{\mathrm{f}} \pm 0.55$ & $5.2^{\mathrm{bc}} \pm 0.84$ & $5.0^{c \mathrm{~d}} \pm 0.71$ & $3.2^{\mathrm{e}} \pm 0.45$ & $5.6^{\mathrm{bc}} \pm 0.89$ & $4.2^{\mathrm{b}} \pm 0.45$ \\
\hline $\begin{array}{l}\text { MSNAPP } \\
(32.75 \%)\end{array}$ & $5.4^{\mathrm{b}} \pm 0.89$ & $5.0^{c} \pm 0.71$ & $3.8^{\mathrm{d}} \pm 0.84$ & $4.0^{e} \pm 1.0$ & $3.2^{\mathrm{e}} \pm 0.45$ & $2.8^{\mathrm{e}} \pm 0.45$ & $3.2^{\mathrm{d}} \pm 0.45$ & $5.0^{c} \pm 0.00$ & $5.2^{c} \pm 0.45$ & $2.6^{\mathrm{f}} \pm 0.55$ & $5.4^{c} \pm 0.55$ & $3.4^{\mathrm{d}} \pm 0.55$ \\
\hline
\end{tabular}

Values are means \pm standard deviations. Values in a column followed by different letter notations are significantly different at $p \leq 0.05 n=5$. M-Malted.

\begin{tabular}{|c|c|c|c|c|c|}
\hline \multirow{2}{*}{ Composite } & \multicolumn{5}{|c|}{ Aftertaste } \\
\hline & Malty aftertaste & cooked cowpea & Finger millet & Presence of residue & Astringency \\
\hline KNE741 (0\%) & $1.4^{\mathrm{f}} \pm 0.89$ & $1.2^{\mathrm{h}} \pm 0.45$ & $4.6^{\mathrm{d}} \pm 0.89$ & $2.4^{\mathrm{e}} \pm 0.89$ & $5.4^{\mathrm{b}} \pm 0.89$ \\
\hline KNE741 (21.26\%) & $1.0^{\mathrm{f}} \pm 0.00$ & $4.8^{c} \pm 0.84$ & $3.8^{\mathrm{e}} \pm 0.84$ & $1.8^{\mathrm{f}} \pm 0.45$ & $3.6^{\mathrm{f}} \pm 0.55$ \\
\hline KNE741 (32.75\%) & $3.4^{\mathrm{d}} \pm 1.14$ & $4.2^{\mathrm{de}} \pm 0.45$ & $3.8^{\mathrm{e}} \pm 0.45$ & $3.4^{\mathrm{d}} \pm 0.89$ & $4.4^{\mathrm{d}} \pm 0.89$ \\
\hline MKNE741 (0\%) & $5.8^{\mathrm{a}} \pm 0.84$ & $2.6^{\mathrm{g}} \pm 0.55$ & $1.8^{\mathrm{h}} \pm 0.45$ & $4.4^{\mathrm{c}} \pm 0.89$ & $2.8^{\mathrm{gh}} \pm 0.84$ \\
\hline MKNE741 (21.26\%) & $4.4^{\mathrm{bc}} \pm 0.55$ & $4.0^{\mathrm{e}} \pm 0.71$ & $3.4^{\mathrm{f}} \pm 0.89$ & $3.8^{\mathrm{d}} \pm 0.45$ & $1.6^{\mathrm{i}} \pm 0.55$ \\
\hline MKNE741 (32.75\%) & $4.4^{\mathrm{bc}} \pm 0.55$ & $5.4^{\mathrm{b}} \pm 0.55$ & $2.4^{\mathrm{g}} \pm 0.55$ & $4.2^{\mathrm{cd}} \pm 0.84$ & $2.0^{\mathrm{h}} \pm 0.00$ \\
\hline SNAPP (0\%) & $2.6^{e} \pm 0.89$ & $2.6^{\mathrm{g}} \pm 0.55$ & $6.8^{\mathrm{a}} \pm 0.45$ & $6.2^{\mathrm{a}} \pm 0.84$ & $6.0^{\mathrm{a}} \pm 0.71$ \\
\hline SNAPP (21.26\%) & $3.2^{\mathrm{d}} \pm 0.45$ & $4.2^{\mathrm{de}} \pm 1.10$ & $5.2^{c} \pm 0.84$ & $4.4^{c} \pm 1.34$ & $5.0^{c} \pm 0.71$ \\
\hline SNAPP (32.75\%) & $4.0^{c} \pm 0.71$ & $5.8^{\mathrm{a}} \pm 0.45$ & $6.0^{\mathrm{b}} \pm 0.71$ & $5.0^{\mathrm{b}} \pm 1.00$ & $4.0^{\mathrm{e}} \pm 0.71$ \\
\hline MSNAPP (0\%) & $5.2^{\mathrm{a}} \pm 0.84$ & $3.0^{\mathrm{f}} \pm 0.71$ & $3.4^{\mathrm{f}} \pm 1.14$ & $2.4^{\mathrm{d}} \pm 0.89$ & $3.0^{g} \pm 0.00$ \\
\hline MSNAPP (21.26\%) & $5.6^{\mathrm{a}} \pm 0.55$ & $4.4^{\mathrm{d}} \pm 0.55$ & $3.6^{\mathrm{ef}} \pm 0.55$ & $3.4^{\mathrm{d}} \pm 0.55$ & $3.0^{g} \pm 0.71$ \\
\hline MSNAPP (32.75\%) & $4.6^{\mathrm{b}} \pm 0.89$ & $4.8^{c} \pm 0.84$ & $3.2^{\mathrm{f}} \pm 0.45$ & $4.2^{\mathrm{cd}} \pm 0.84$ & $2.0^{\mathrm{h}} \pm 0.00$ \\
\hline
\end{tabular}

Values are means \pm standard deviations. Values in a column followed by different letter notations are significantly different at $\mathrm{p} \leq 0.05, \mathrm{n}=5$. 
Samples composited at $21.26 \%$ and $32.75 \%$ had a significant effect $(\mathrm{p}<0.05$ ) on malty and cooked cowpea flavour characteristics with the latter predominating as the ratio increased. There was also a concomitant reduction in astringency aftertaste as more cowpea was added. Cooked cowpea, instead of characteristic beany flavour associated with most legumes, contain a roasted nut flavour due to action of sugars and protein when they exposed to drying temperatures after cooking. This resulted a significantly $(\mathrm{p}<0.05)$ higher values in composites composted at $32.75 \%$ than $21.26 \%$.

\section{PCA characteristics of sensory attributes of complementary porridge}

Principal component analysis was used to extract important information from the heterogeneous data, and reduce set of correlated variables to uncorrelated measures (principal components) without loss of original information [33]. The first four (PC's) accounted for approximately over $80 \%$ of the total variation observed $(\mathrm{PC} 1=54 \%, \mathrm{PC} 2=12 \%, \mathrm{PC} 3=10 \%, \mathrm{PC} 4=6 \%)$. Various researchers have identified different principal components. Anyango et al. [13], working on the effect of compositing cowpea on sorghum foods extracted two major principal components that accounted for over $97 \%$ of total variation in seventeen sensory attributes of thick porridge. Kayitesi et al. [34] working on sensory attributes of pre-conditioned cowpea subjected to micronisation, were able to extract three major principal component that accounted for over $93 \%$ of total variation. Aroma property malty), texture properties (viscosity, coarseness and stickiness), Flavour properties (overall flavour, malty and burnt), and aftertaste (malty and astringency), characterised PC1. The second PC was defined by aroma attributes (overall aroma intensity and finger millet aroma), millet aftertaste and presence of residue, while the third PC was characterized by cowpea aftertaste and cooked cowpea flavour. Malting resulted in antagonistic relationship among sensory attributes (Table 4). There was a positive relationship (Table 4) associated with malty aroma, malty flavour, and malty aftertaste, and a negative relationship in texture attributes (stickiness and viscosity) and astringency aftertaste. This implies that, malting process had positive effect on sensory attributes of the complementary food a desirable malty flavour and aroma properties, as described in results under mean values. This was in agreement with correlation coefficient results, as malty aroma and malty aftertaste were highly significant at 0.53 and 0.54 , respectively, to overall flavour. Moreover, in PC1 astringency was negatively related at 0.78 , this further explains importance of malting and compositing on complementary porridges. Astringency is because of high levels of bitter condensed tannins and polyphenols found in unmalted millet flour [28]. When finger millet is malted level of tannins and polyphenols are reduced by action of inherent hydrolytic enzymes such as polyphenol oxidase to lower molecular weight compounds that are less bitter [25]. Additionally, compositing malted millet flour with precooked cowpea flour (has low amount of polyphenols), further reduces astringency of the complementary finger millet porridge.

An attribute that was uniquely prominent in PC3, was roasted nut flavour (described by panellists as cooked cowpea flavour), associated with compositing 
precooked of cowpea and had a positive loading of approximately 0.80 that influenced the overall flavour and aroma intensity of complementary finger millet porridge. The attribute seemed to be unfamiliar to complementary porridge consumers, because of its low correlation coefficient $(-0.10)$ which was not significant to overall flavour. The findings were in agreement with Kayitesi et al. [34] who observed that roasted nut flavour was undesirable to consumers when pre-conditioned cowpeas were subjected to micronisation. Various researchers have reported beany flavour as a hindrance to acceptability of cereal-legume composited foods [14] [35]. Anyango et al. [14] for example, was able to identify beany flavour typical with legumes, when sorghum, was composited with $30 \%$ cowpea. However, cooking resulted in thermal destruction of lipoxygenase enzymes that catalyses formation of odorous compounds such as 2-pentenyl furan, which are responsible for the beany flavour [14]. This explains the absence of beany flavour in the complementary porridge prepared.

Correlations loading plot for the complementary sensory attributes for the first three PCs represented in Figure 1. Measurement close to each other are positively related, while those that are negatively related are separated by $180^{\circ}$, and those that are separated by $90^{\circ}$ are independent and therefore they would be loaded on different PCs [33]. This therefore means that, interpretation and measurement of PCs was according to the correlations between each parameter and each PCs. In Figure 1(a), stickiness, and viscosity of complementary porridge had a negative loading and were placed far in the first PC. They were critical parameters that defined PC1, and their negative loading had a huge implication, in that, a decrease would result in an increase in PC. Similarly, burnt flavour, malty aftertaste, malty flavours were far in $\mathrm{PC} 1$, with a positive loading. It therefore meant an increase in these sensory attributes would result in an increase in PC1.

Moreover, millet flavour and millet aftertaste were closely located having a positive correlation, but negatively correlated to cooked cowpea aroma and cowpea aftertaste, located in the opposite quadrant, which can be attributed to varying level of precooked cowpea flour used. Malty flavour, malty aftertaste and malty aroma were located close to overall flavour and aroma sensory attributes, showing that the three parameters were important in defining the flavour of the complementary porridge. In the present work therefore, showed that, composites that were viscous, stick and astringent aftertaste attributes were lowly rated hence less desired. Negative correlation of viscosity and stickiness in Figure 1 (a), to malty flavour and aroma, showed the importance of malting process in formulating complementary baby weaning food.

In Figure 1(b) cowpea, aftertaste and cooked cowpea flavour were negatively correlated to astringency with latter being close to PC3. Its closeness to PC3 showed its importance in influencing PC3 loadings as compared to neither cooked cowpea flavour nor cowpea aftertaste.

Figure 2 shows the scores biplot for PC1 versus PC2 for KNE 741, Snapping, Unmalted, malted, $0 \%, 21.26 \%$ and $32.75 \%$. According to Mwove et al. [33] 


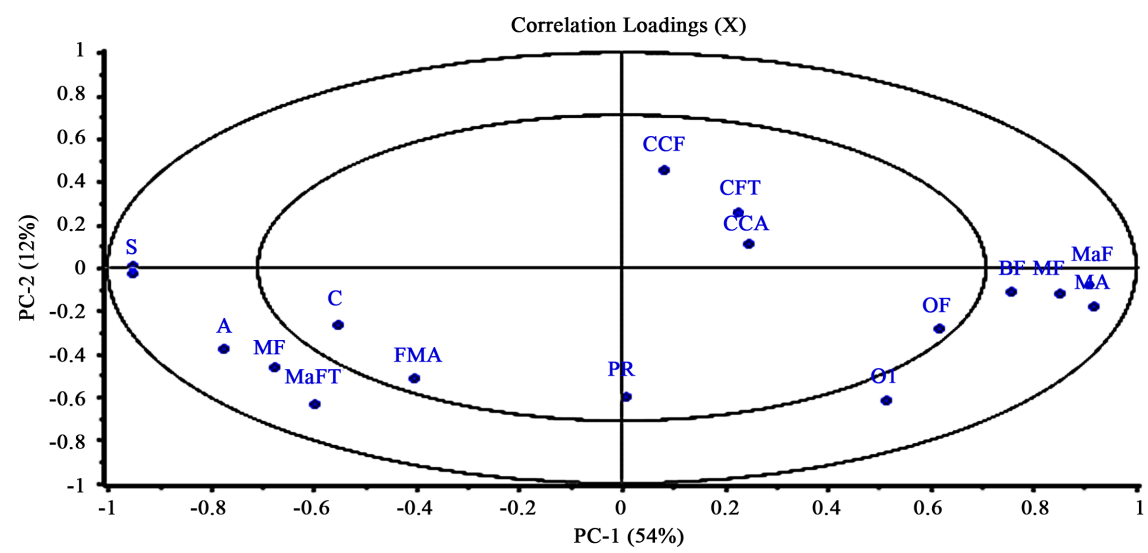

(a)

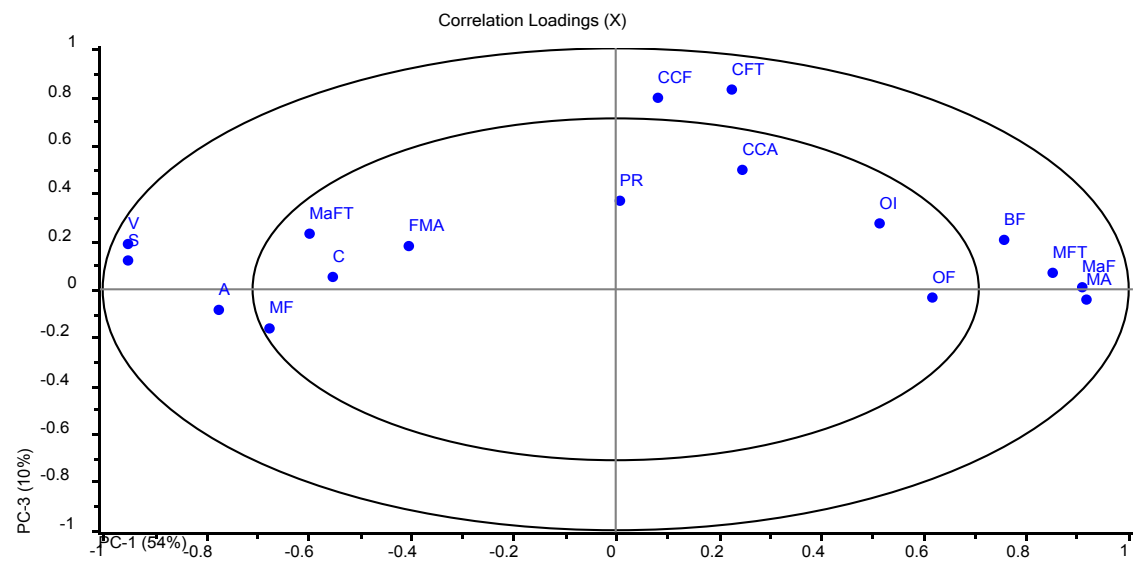

(b)

Figure 1. Biplot for (a) PC 1 and PC 2, and (b) PC 1 and PC 3. Key: OI-overall intensity, MA-malty aroma, CCA-cooked cowpea aroma, FMA-finger millet aroma, C-coarseness, V-viscosity, S-stickiness, OF-overall flavour, CCF-cooked cowpea flavour, MF_-millet flavour, MAF — malty flavour, BF—burnt flavour, MFT — malty aftertaste, CFT — cowpea aftertaste, MAFT—millet aftertaste, PR—Presence of residue, A—astringency.

score plot represents loadings of sensory attributes in the multivariate space of two PC score vectors. From the figures, two samples were clearly distinguished based on the sensory attributes. Two varieties used had distinguishable sensory attributes (Figure 2(a)) with KNE 741 associated with high level of stickiness and astringency because of high amount of polyphenol in the grains (Table 2) than snapping Green Earlyvariety.

In Figure 2(b), unmalted samples were located on the left side near (stickiness, viscosity, astringency); while after malting process the samples were located on the right side near malty flavour and malty aroma. This shows that malting had influence on sensory attribute of the composite flour. In Figure 2 (c), composites containing $32.75 \%$ precooked cowpea were associated strongly with cooked cowpea flavour and aroma, this meant that although they were less viscous and stick they contained a distinctive cooked cowpea flavour (roasted nut flavour), that influenced PC3 loading. 

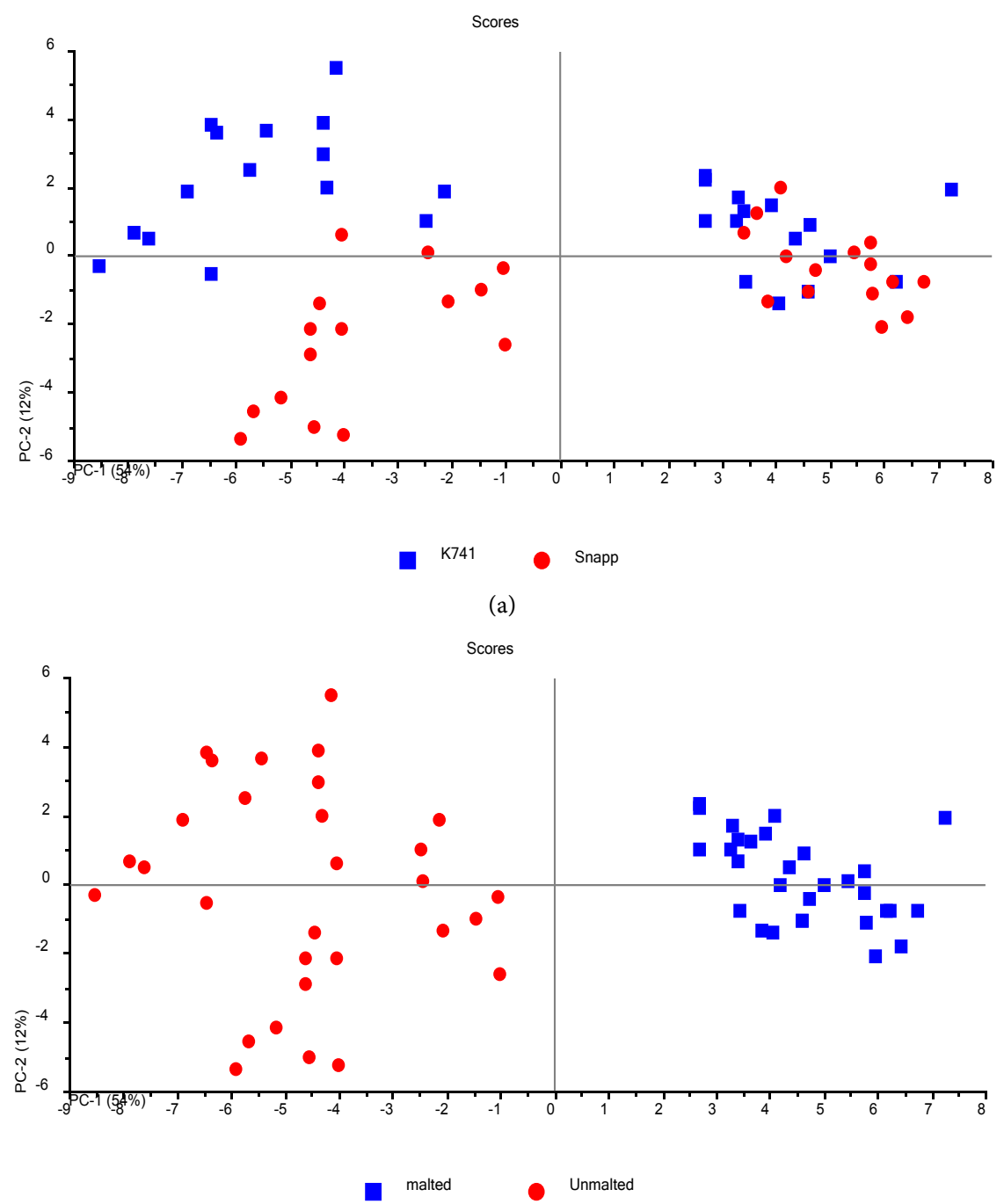

(b)

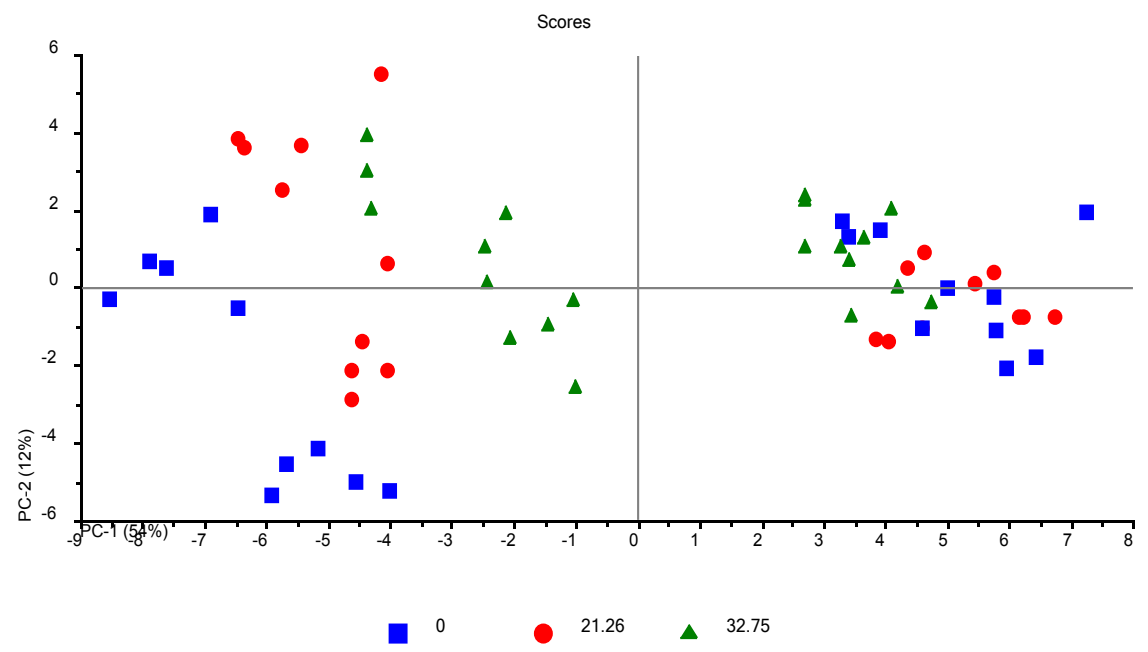

(c)

Figure 2. Scores biplot for (a) PC1 versus PC2, for KNE 741 and Snapping finger millet varieties (b); PC1 versus PC2, for Malted and Unmalted finger millet (c); PC1 versus PC2, for $0 \%$ (100\% finger millet), $21.26 \%$ precooked cowpea and $32.75 \%$ precooked cowpea. 


\section{Conclusion}

Malting decreases anti-nutrient content with a concomitant increase in nutrient profile of complementary foods. In the present study, tannin content, phytic acid and total phenol content notably decreased by $50 \%$, $44 \%$ and $41 \%$, respectively, after compositing with malted finger millet and precooked cowpea. In addition, malting of finger millet varieties positively influences the sensory attributes in terms of malty flavour, malty aroma and malty aftertaste as they were closely related and were negatively correlated to viscosity and stickiness. Furthermore, malty flavour and malty aftertaste significantly influence overall flavour, based on correlation coefficient results of 0.53 and 0.54 respectively. Based on these observations it is feasible to composite malted finger millet and precooked cowpea at $32.75 \%$, however, this high level results in a distinctive cooked cowpea flavour that will have to be masked by commercial flavours available in commercial market. Therefore, compositing malted finger millet with precooked cowpea can be used in formulating a cultural acceptable complementary food that can be used to curb Protein energy malnutrition in Kenya.

\section{Acknowledgements}

The research was funded by the Centre of Excellence for Sustainable Agriculture and Agribusiness Management (CESAAM), World Bank funded project at Egerton University, Kenya. Thanks to Agro-science park for the supply of seed varieties.

\section{Conflicts of Interest}

The authors declare no conflicts of interest regarding the publication of this paper.

\section{References}

[1] Sajilata, G., Singhal, R.S. and Kulkarni, P.R. (2002) Weaning Foods: A Review of the Indian Experience. Food and Nutrition Bulletin, 23, 208-226. https://doi.org/10.1177/156482650202300210

[2] Alexander, C.M. (1983) Preparation of Weaning Foods with High Nutrient Density Using Flour of Germinating Cereals. Food and Nutrition Bulletin, 5, 10-14.

[3] Michaelsen, K.F., Hoppe, C., Roos, N., Kaestel, P., Stougaard, M., Lauritzen, L. and Friis, H. (2009) Choice of Foods and Ingredients for Moderately Malnourished Children 6 Months to 5 Years of Age. Food and Nutrition Bulletin, 30, S343-S404. https://doi.org/10.1177/15648265090303S303

[4] Oniang'o, R., Mutuku, J. and Malaba, S.J. (2003) Contemporary African Food Habits and Their Nutritional and Health Implications. Asia Pacific Journal of Clinical Nutrition, 12, 331-336.

[5] Konyole, S.O., Kinyuru, J.N., Owuor, B.O., Kenji, G.M., Onyango, C.A., Estambale, B.B. and Owino, V.O. (2012) Acceptability of Amaranth Grain-Based Nutritious Complementary Foods with Dagaa Fish (Rastrineobola argentea) and Edible Termites (Macrotermessubhylanus) Compared to Corn Soy Blend plus among Young Children/Mothers Dyads in Western Kenya. Journal of Food Research, 1, 111-112. 
https://doi.org/10.5539/jfr.v1n3p111

[6] Ogbonna, A.I., Akueshi, E.U., Aguiyi, U.B., Onosemuode, A., Emefiene, M.M. and Okunuga, D.O. (2010) Nutrient Analysis of Indigenous Fortified Baby Weaning Foods from Nigerian Cereals. Nigerian Journal of Biotechnology, 21, 41-45.

[7] Owino, V.O., Sinkala, M., Amadi, B., Tomkins, A.M. and Filteau, S.M. (2007) Acceptability, Storage Stability and Costing of $\alpha$-Amylase-Treated Maize-BeansGroundnuts-Bambaranuts Complementary Blend. Journal of the Science of Food and Agricultured, 87, 1021-1029. https://doi.org/10.1002/jsfa.2799

[8] Bavec, F. and Bavec, M. (2007) Organic Production and Use of Alternative Crops. CRC Press/Taylor and Francis Group, Boca Raton, 119-120.

https://doi.org/10.1201/9781420017427

[9] Siwela, M., Taylor, J.R., de Milliano, W.A. and Duodu, K.G. (2007) Occurrence and Location of Tannins in Finger Millet Grain and Antioxidant Activity of Different Grain Types. Cereal Chemistry, 84, 169-174. https://doi.org/10.1094/CCHEM-84-2-0169

[10] Ojwang, L.O. (2012) Anti-Inflammatory Properties of Cowpea Phenotypes with Different Phenolic Profiles. Doctoral Thesis, Texas A\&M University, College Station. https://doi.org/10.1094/CPLEX-2011-1013-04W

[11] Onyenekwe, P.C., Njoku, G.C. and Ameh, D.A. (2000) Effect of Cowpea (Vigna unguiculata) Processing Methods on Flatus Causing Oligosaccharides. Nutrition Research, 20, 349-358. https://doi.org/10.1016/S0271-5317(00)00128-7

[12] Vilakati, N., MacIntyre, U., Oelofse, A. and Taylor, J.R. (2015) Influence of Micronization (Infrared Treatment) on the Protein and Functional Quality of a Readyto-Eat Sorghum-Cowpea African Porridge for Young Child Feeding. LWT Food Science and Technology, 63, 1191-1198. https://doi.org/10.1016/j.lwt.2015.04.017

[13] Anyango, J.O., De Kock, H.L. and Taylor, J.R.N. (2011) Impact of Cowpea Addition on the Protein Digestibility Corrected Amino Acid Score and Other Protein Quality Parameters of Traditional African Foods Made from Non-Tannin and Tannin Sorghum. Food Chemistry, 124, 775-780. https://doi.org/10.1016/j.foodchem.2010.06.094

[14] Anyango, J.O., de Kock, H.L. and Taylor, J.R. (2011) Evaluation of the Functional Quality of Cowpea-Fortified Traditional African Sorghum Foods Using Instrumental and Descriptive Sensory Analysis. LWT-Food Science and Technology, 44, 2126-2133. https://doi.org/10.1016/j.lwt.2011.07.010

[15] Mbithi-Mwikya, S., Van Camp, J.Y. and Huyghebaert, A. (2000) Nutrient and Anti-Nutrient Changes in Finger Millet during Sprouting. LWT-Food Science and Technology, 33, 9-14. https://doi.org/10.1006/fstl.1999.0605

[16] WHO (2007) Protein and Amino Acid Requirements in Human Nutrition. WHO/FAO/UNU Technical Report Series No. 935. World Health Organization Press, Geneva.

[17] AACC International (2000) Approved Methods of the American Association of Cereal Chemists. 11th Edition, Methods 44-15a and 46-10.01. The Association, St. Paul.

[18] Singleton, V.L. and Rossi, J.A. (1965) Colorimetry of Total Phenolics with Phosphomolybdic-Phosphotungstic Acid Reagents. American Journal of Enology and Viticulture, 16, 144-158.

[19] Price, M.L., Van Scoyoc, S. and Butler, L.G. (1978) A Critical Evaluation of the Vanillin Reaction as an Assay for Tannin in Sorghum Grain. Journal of Agricultural and Food Chemistry, 26, 1214-1218. https://doi.org/10.1021/jf60219a031 
[20] Makkar, H.P., Siddhuraju, P. and Becker, K. (2007) Plant Secondary Metabolites. Humana Press, Totowa.

[21] Meilgaard, M., Civille, G.V. and Carr, B.T. (2007) Sensory Evaluation Techniques. 4th Edition, CRC Press, Boca Raton, 225-311.

[22] Naczk, M. and Shahidi, F. (2004) Extraction and Analysis of Phenolics in Food. Journal of Chromatography, 1054, 95-111. https://doi.org/10.1201/9780203508732

[23] Singh, P. and Raghuvanshi, R.S. (2012) Finger Millet for Food and Nutritional Security. African Journal of Food Science, 6, 77-84.

https://doi.org/10.5897/AJFSX10.010

[24] Waterman, P.G. and Mole, S. (1994) Analysis of Phenolic Plant Metabolites. Blackwell Scientific Publications, Oxford, 73-99.

[25] Hejazi, S.N. and Orsat, V. (2016) Malting Process Optimization for Protein Digestibility Enhancement in Finger Millet Grain. Journal of Food Science and Technology, 53, 1929-1938. https://doi.org/10.1007/s13197-016-2188-x

[26] Sripriya, G., Antony, U. and Chandra, T.S. (1997) Changes in Carbohydrate, Free Amino Acids, Organic Acids, Phytate and $\mathrm{HCl}$ Extractability of Minerals during Germination and Fermentation of Finger Millet (Eleusine coracana). Food Chemistry, 58, 345-350. https://doi.org/10.1016/S0308-8146(96)00206-3

[27] Emmambux, N.M. and Taylor, J.R.N. (2003) Sorghum Kafirin Interaction with Various Phenolic Compounds. Journal of Science and Food Agriculture, 83, 402-407. https://doi.org/10.1002/jsfa.1379

[28] Awika, J.M., Dykes, L., Gu, L., Rooney, L.W. and Prior, R.L. (2003) Processing of Sorghum (Sorghum bicolor) and Sorghum Products Alters Procyanidin Oligomer and Polymer Distribution and Content. Journal of Agriculture and Food Chemistry, 51, 5516-5521. https://doi.org/10.1021/jf0343128

[29] Taylor, J.R. and Duodu, K.G. (2015) Effects of Processing Sorghum and Millets on Their Phenolic Phytochemicals and the Implications of This to the Health-Enhancing Properties of Sorghum and Millet Food and Beverage Products. Journal of the Science of Food and Agriculture, 95, 225-237. https://doi.org/10.1002/jsfa.6713

[30] Shibairo, S.I., Nyongesa, O., Onwonga, R. and Ambuko, J. (2014) Variation of Nutritional and Anti-Nutritional Contents in Finger Millet (Eleusine coracana (L.) Gaertn) Genotypes. IOSR Journal of Agriculture and Veterinary Science, 7, 6-12. https://doi.org/10.9790/2380-071110612

[31] Ngure, K.S., Indieka, A.S., John, N. and Peter, N. (2016) Nutritional, Rheological and Organoleptic Properties of Whole Meal Flour Prepared from Stem Rust Resistant Wheat Varieties Released in Kenya. World Journal of Agricultural Research, 4, 173-182.

[32] Traoré, T., Mouquet, C., Icard-Vernière, C., Traore, A.S. and Trèche, S. (2004) Changes in Nutrient Composition, Phytate and Cyanide Contents and $\alpha$-Amylase Activity during Cereal Malting in Small Production Units in Ouagadougou (Burkina Faso). Food Chemistry, 88, 105-114. https://doi.org/10.1016/j.foodchem.2004.01.032

[33] Mwove, J.K., Gogo, L.A., Chikamai, B.N., Omwamba, M. and Mahungu, S.M. (2018) Principal Component Analysis of Physicochemical and Sensory Characteristics of Beef Rounds Extended with Gum Arabic from Acacia Senegal var. Kerensis. Food Science \& Nutrition, 6, 474-482. https://doi.org/10.1002/fsn3.576

[34] Kayitesi, E., Duodu, K.G., Minnaar, A. and de Kock, H.L. (2013) Effect of Micronisation of Pre-Conditioned Cowpeas on Cooking Time and Sensory Properties of Cooked Cowpeas. Journal of the Science of Food and Agriculture, 93, 838-845. 
https://doi.org/10.1002/jsfa.5805

[35] Asma, M.A., Fadil, E.B. and Tinay, A.H. (2006) Development of Weaning Food from Sorghum Supplemented with Legumes and Oil Seeds. Food and Nutrition Bulletin, 27, 26-34. https://doi.org/10.1177/156482650602700104 